\author{
Per Esben Myren-Svelstad \\ Noregs teknisk-naturvitskaplege universitet (NTNU)
}

DOI: http://dx.doi.org/10.5617/adno.7811

\title{
Det affektive møtet mellom tekst og lesar: Tre postkritiske inngangar til å velja skjønnlitteratur i morsmålsfaget
}

\begin{abstract}
Samandrag
Artikkelen identifiserer val av skjønnlitteratur som ein kjernepraksis i morsmålsundervisninga, der det i liten grad finst forsking på eksisterande praksis og teoretiske grunnlagsproblem. Det er til det sistnemnde feltet artikkelen søkjer å bidraga, ved å opne opp og nyansere diskusjonen om premissar for litteraturval. Artikkelen er todelt. Den fyrste delen er ei metateoretisk drøfting av dei ulike syna på skjønnlitteratur og litteraturundervisning som er i spel i kanon- og utvalsdebattar. Drøftinga bruker dikotomien kvalitet/representativitet som tankefigur for å klårgjera skiljeliner, samanfall og uteoretiserte premissar i dei ulike haldningane. Med utgangspunkt i dette blir det argumentert for at eit dialogisk syn på litterær kompetanse, saman med postkritisk teori, kan danne eit meir fruktbart utgangspunkt for å reflektere over kva litteraturen gjer i møte med lesarar, og dimed kva for grunnlag ein vel litteratur ut frå. Den andre delen føreslår å didaktisere postkritisk teori ved å skildre tre inngangar til litteraturvalet. Desse inngangane kan sjåast som grunnlag for å velja litteratur, men òg som kategoriar for å skildre kva som skjer i møtet mellom lesarar og dei skjønnlitterære tekstene i morsmålsfaget. Avslutningsvis blir den presumptive konflikten mellom estetisk utforsking og didaktisk målstyring drøfta, og det blir argumentert for at litteratursynet artikkelen skildrar, stør opp under ei problembasert litteraturundervisning.
\end{abstract}

Nøkkelord: litteraturdidaktikk, litterær kompetanse, litterær kanon, litterær etikk, postkritikk, affektteori

\section{The affective encounter between text and reader: Three postcritical approaches to the choice of literature in L1 education}

\begin{abstract}
The article identifies the selection of literature as a core practice in L1 education on which there is a limited amount of research on existing practices and theoretical assumptions. Seeking to contribute to the latter, the article suggests ways to open and nuance the discussion around the selection of literature. The article consists of two main parts. The first part offers a metatheoretical discussion of the differing views on imaginative literature and literary education at stake in discussions of the literary canon and literature selection. The discussion employs the dichotomy quality/representativity as analytical
\end{abstract}


category in order to highlight fissures, overlaps and untheorized assumptions in the differing viewpoints. Hence, it is argued that a dialogical understanding of literary competence, in conjunction with postcritical theory, may form a more productive starting point for reflections on what literature does in encounters with readers, and thus on what basis literary texts are selected. The second part of the article suggests a pedagogization of postcritical theory by describing three approaches to the selection of literature. These approaches can be regarded as a basis for selection, but also descriptive categories of what happens in the encounter between readers and texts in the context of L1 education. In conclusion, the supposed conflict between aesthetical exploration and pedagogical management by objectives is discussed, and it is argued that the notion of literature described in the article supports a problem-based literary instruction.

Keywords: literary education, literary competence, literary canon, literary ethics, postcritical theory, affect theory

\section{Innleiing}

Ein norsklærar på 10. trinn skal velja litterære tekster for klassa si. For å leva opp til føremålet om djuplæring bestemmer ho seg for å velja nokre få tekster som kan lesast og drøftast i ljos av kvarandre. Ho må sikre at elevane blir kjende med noko av det beste i norsk litteratur: eit stykke av Ibsen, ei novelle av Skram, nokre dikt av Bjørnson. For å få til historisk spreiing tek ho også med dikt av Hauge, viser av Prøysen og Is-slottet av Vesaas.

Men vent - det er berre med éin kvinneleg forfattar så langt. Og ingen samiske eller nolevande. Mellom verdener av Máret Ánne Sárá fyller alle kvotane. Men for at det ikkje skal bli for mange bøker, må noko ut. Er Mellom verdener god nok til å erstatte Is-slottet? Eller forresten - i og med at Vesaas er ein forfattar med lokal tilknyting, bør han få stå. Kven skal då ut - Ibsen, Bjørnson, Prøysen eller Hauge? Kva for kriterium skal vega tyngst i utvalet av litteratur?

Denne artikkelen utviklar kunnskapen om litteraturval i morsmålsfaget gjennom ein teoretisk premissdiskusjon. I det fylgjande gjev eg ein kort presentasjon av tidlegare skandinavisk forsking på kva som blir lese i morsmålsfaget. Deretter drøftar eg det eg identifiserer som ein grunnleggjande dikotomi, nemleg dei to vurderingskriteria kvalitet og representativitet. I denne metateoretiske delen argumenterer eg for å sjå ein dialogisk modell for litterær kompetanse (Torell, 2002) i samanheng med postkritisk teori (Felski, 2015). Slik vil eg underbyggje at den didaktiske praksisen litteraturval bør ta utgangspunkt $\mathrm{i}$ «richer and deeper accounts of how selves interact with texts» (Felski, 2008, s. 11). Deretter konkretiserer eg korleis teorigrunnlaget kan implementerast i litteraturundervisning, noko som er det sentrale kunnskapsbidraget i artikkelen. Her skisserer eg tre inngangar til litteraturval, som òg kan fungere som deskriptive kategoriar for det som skjer i møtet mellom tekst og lesar. Med grunnlag i dialogisk og postkritisk tenking skal dei tre inngangane svara på hovudspørsmålet for artikkelen: 
Korleis kan litterær motstand og det uføreseielege fungere som ressursar i arbeidet med å velja tekster for å utvikle litterær kompetanse?

Diskusjonen av dette munnar ut i eit omgrep om affektiv hermeneutikk (Felski, 2015). Det sentrale kunnskapsbidraget i artikkelen er dimed for det fyrste å gjeva ein kritisk diskusjon av nokre grunnleggjande litteraturdidaktiske premissar og for det andre å vise korleis postkritiske perspektiv kan nyttast i valet av tekster. Artikkelen er del av prosjektet «Digital kanon i norskfaget» ved NTNU i Trondheim. ${ }^{1}$ Sjølv om artikkelen er relevant for skandinavisk morsmålsdidaktikk generelt, vel eg, for å avgrense drøftinga, å referere til den nye norske læreplanen, den såkalla Fagfornyinga (Utdanningsdirektoratet, 2019).

\section{Bakgrunn og tidlegare forsking}

Trass i at å velja tekster er ei kjerneoppgåve i litteraturundervisning, finst det forholdsvis lite forsking på feltet. Som danskdidaktikaren Martin Blok Johansen poengterer, dreiar forskinga seg oftast om «litteraturundervisningens hvordan, og i mindre grad med dens hvad» (2015, s. 4). Forskinga på feltet har grovt sett vore basert på tre tilnærmingar: (1) studiar av læreverk (f.eks. Aamotsbakken, 2003, 2015); (2) studiar av styringsdokument (f.eks. Hamre, 2014; Persson, 2007; Steinfeld, 2009); (3) observasjonar og intervju av lærarar og elevar (f.eks. Kjelen, 2013; Penne, 2006). Ei fjerde og meir teoretisk-prinsipiell tilnærming er å drøfte kanonproblematikk i ljos av litteraturen som samfunnsinstitusjon og særskilt kunnskapsobjekt (f.eks. Haarberg, 2017; Weinreich, 2004). I tillegg viser fleire nyare intervensjonsstudiar verdien av arbeid med utfordrande litteratur (f.eks. Johansen, 2015; Sønneland, 2019). Å eksperimentere med utradisjonelle tekster, framfor å studere allereie eksisterande praksis, utgjer ein ny tendens i forskinga. Hovudlina i forskingsresultata er likevel klår: Trass i massemedialiseringa og det utvida tekstomgrepet er litteraturval ofte knytt til ei allmenn oppfatning om kva for tekster som utgjer den nasjonale kanon, og til tekster som blir traderte på dei ulike skulane gjennom undervisningsopplegg og lærebøker (Aamotsbakken, 2003; Kjelen, 2013, s. 202; Persson, 2007, s. 77; Skaug \& Blikstad-Balas, 2019, s. 95; Weinreich, 2004, s. 15-16). Det føregår med andre ord ei form for «skjult» kanondanning (Vinje, 2005).

I ein observasjonsstudie av ungdomstrinnet finn Gabrielsen, Blikstad-Balas og Tengberg (2019) at tre faktorar er dominerande i valet og bruken av tekster. For det fyrste er lærebøkene, som inneheld stor sjangervariasjon, ofte styrande. For det andre vel elevar individuelt bøker til stille lesing. Dette resulterer i at skulen bidreg til å forsterke dei forskjellane i tilgang på variert skjønnlitteratur som allereie eksisterer mellom elevane. For det tredje er norskundervisninga i stor grad prega av at sjangertrekk og verkemiddel blir vektlagde. Effekten av skjønnlitterær

${ }^{1} \mathrm{Jf}$. nettsida til forskingsgruppa: https://www.ntnu.no/ilu/digital-kanon-i-norskfaget 
lesing blir såleis i liten grad diskutert og nytta som grunnlag for valet og bruken av tekstene. For den vidare drøftinga i denne artikkelen er det særleg relevant å merke seg at ei snever vektlegging av sjangertrekk gjev få rettesnorer for valet av skjønnlitteratur, og at spørsmålet om kva elevane kan få ut av litterære tekster på eit estetisk, epistemologisk eller eksistensielt nivå, likeins risikerer å bli avgløymd.

I både Noreg og Sverige har tendensen i styringsdokument vore å leggje til rette for at den kanoniserte nasjonallitteraturen skal lesast nokså ukritisk, medan dei nye massemediale tekstformene skal tolkast og drøftast kritisk (Hamre, 2014, s. 480; Persson, 2007, s. 87). Dette kan forklårast ut frå ei uproblematisert førestilling om at «[d]en litteratur eleverna kommer i kontakt med i skolan är god» (Persson, 2007, s. 86). For kvalitetsomgrepet blir sjeldan problematisert; til dømes finn ein sjeldan eksplisitte kvalitetsnormer i norske lærebøker (Aamotsbakken, 2008, s. 148). Torben Weinreich er inne på det same når han hevdar at «[a]t opstille en kanon er i virkeligheden at åbne en ellers skjult proces», og at valet av litteratur med fordel kan byggje på «eksplicitte overvejelser, måske oven i købet nedfældede principper for valg» (Weinreich, 2004, s. 26). Det er likevel ikkje dimed sagt at å setja opp ei bestemt verkliste er den beste måten å skapa medvit om kriteria for litteraturutvalet på. Like didaktisk verdfullt kan det vera å halde i gong ein fagleg debatt om kva for kriterium som kan og bør styre valet av litteratur. Kva er god litteratur, dersom skulen ikkje berre skal kunna velja tekster frå ein førehandsbestemt kanon? Og korleis kan vi vita om den litterære kanon er kvalitativt god i ljos av dei institusjonelle krava skulen stiller?

Skandinavisk morsmålsdidaktikk manglar med andre ord ei metateoretisk samtale om grunnlagspremissane for litteraturval. Føremålet med denne artikkelen er ikkje å munne ut i ferdige retningsliner, men å opne opp denne samtala. Artikkelen tek utgangspunkt i at den stadige debatten «for» eller «imot» ein fast kanon er lite fruktbar, nettopp fordi mange av premissane for litteraturutvalet ikkje i tilstrekkeleg grad er drøfta kritisk. Hallvard Kjelen påpeiker at kanonomgrepet og andre omgrep knytt til det bør analyserast kritisk i litteraturdidaktikken, mellom anna fordi dei «tvingar oss til å tenkje på bestemte måtar, ofte dikotomisk» (2013, s. 206). I det fylgjande går eg éin slik dikotomi, nemleg kvalitet og representativitet, nærare etter i saumane, ut frå ei oppfatning av at denne er grunnleggjande i kanondebatt og litterære utvalspraksisar utan at han er tilstrekkeleg konseptualisert.

\section{Teoretiske premissar}

\section{Kvalitet og representativitet}

Med kvalitet forstår eg eit vurderingskriterium som baserer seg på intersubjektive faktorar som at den aktuelle teksta ber på nokre bestemte litterære trekk som blir tillagde høg verdi. Kriteriet er tilsynelatande autonomt, men berre tilsynelatande 
i og med at kvalitetsvurderingar aldri skjer lausrivne frå lesarfellesskap. Med representativitet forstår eg eit vurderingskriterium som kviler på ei implisitt danningsnorm: Skjønnlitteraturen skal presentere lesaren for tekster som representerer ulike samfunnsgrupper, og slik skapa både gjenkjenning for dei som høyrer til den aktuelle gruppa og empatisk forståing hjå dei som ikkje gjer det. I det fylgjande vil eg vise at desse to kriteria framstår som tydelege motpolar i debatten om kva litteraturutvalet, eller den litterære kanon, i morsmålsfaget skal vera. Såleis utgjer skiljet kvalitet/representativitet ein klårgjerande tankefigur for å teoretisk undersøkje implisitte premissar om litteratursyn og litteraturens rolle i skulen.

På den eine sida i utvalsdebattar står dei som meiner ein kan etablere eit utval tekster som meir verdfulle og viktigare enn andre i kraft av eit reindyrka kvalitetskriterium. Den mest kjende målberaren av dette synet er truleg den amerikanske litteraturforskaren Harold Bloom, som hevdar at Vestens store forfattarar har ein transhistorisk og transkulturell estetisk verdi, utan at verka deira dimed skal fungere som rettesnorer for moralske verdiar (1994, s. 29). På den andre sida står kanonkritikarar som gjerne tek utgangspunkt i ei poststrukturalistisk og ideologikritisk forståing av språk og makt. I deira perspektiv underbyggjer det tradisjonelle pensumet ikkje berre i litteraturhistorie, men i alle fag, undertrykkande maktstrukturar. Ifylgje ein kanonkritisk forskar som amerikanske Isaiah Smithson skjer dette med grunnlag i ei rekkje feilaktige premissar:

[...] by conceiving of "reason ... as a timeless essence through which the subject has access to the "truth," which is seen as pancultural'; by assuming that 'literature is a discourse inherently different from other discourses of culture'; by asserting firmly 'that there is a core truth in the text itself'; and, finally, by relying on a view of language that asserts the stability/naturalness of language instead of asserting that language is a 'system of differentiation'. (Smithson, 1994, s. 8)

For kanonkritikarane finst ingen transhistoriske sanningar (venteleg med unnatak for nettopp denne påstanden). Trass i at Smithson stiller seg kritisk til tanken om at litteraturen er ein heilt særeigen type diskurs, tek også kanonkritikarane implisitt utgangspunkt i at litterær lesing har særlege funksjonar. I motsett fall ville det ikkje vore meining i arbeidet for å reformere det tradisjonelle pensumet eller å laga andre retningsliner for valet og bruken av litteratur.

Det er særleg i nordamerikansk kultur, med ei historie prega av eksplisitt rasistisk politikk, at ideologikritiske kanonsyn har vore oppe til debatt. Men ideologikritikken gjev seg i høgste grad utslag også i Norden. Til dømes pågår det ein større diskusjon om avkolonisering av norsk akademia, det vil seia kva for etniske og kulturelle perspektiv og vitskapstradisjonar som bør inkluderast i utdanningssektoren (jf. Lie, 2018). Dette indikerer at kritisk teori har vunne hevd i akademia, og omgrepet «representativitet» blir nytta i skandinavisk kanondebatt (Persson, 2007, s. 9). Då det i Danmark i 1994 vart utarbeidd ei liste over tjue forfattarar før 1900, med Leonora Christina som einaste kvinne, vekte det sterk 
kritikk frå feministisk hald (Weinreich, 2004, s. 20-21). Like fullt har ikkje dette ført til ei radikal omvurdering av kanon i skulesamanheng (Persson, 2007, s. 77). Tvert imot har Aamotsbakken argumentert for at den norske skulens kanoniseringspraksis «heng etter» dei allmenne litteraturhistoriene, for eksempel når det gjeld likeverdig omtale av kvinner (2008, s. 156). Kritikken hennar er tydeleg informert av feministiske perspektiv som nettopp problematiserer idéen om at den tradisjonelle kanon byggjer på ein autonom definisjon av kva litterær kvalitet er. Det er nærliggjande å spekulere i om kanonkritiske perspektiv har vunne innpass i nordiske land på grunn av den dominerande likskapsideologien i desse landa, samtidig som det faktum at kanon i både Noreg, Sverige og Danmark ligg relativt fast, kan indikere at denne kritikken så langt aller mest er ei akademisk øving. I så fall er debatten for og imot ein eksplisitt skulekanon eit kanonkritisk blindspor.

Medan kanonkritikk ut frå representativitetsomsyn er diskursivt utbreidd i Skandinavia, blir kvalitetskriteriet sjeldnare formulert - i alle fall ut frå premissen om transkulturell verdi. Å pledere den kvalitativt gode litteraturen frå eit perspektiv om sosial utjamning tykkjest derimot å vera mindre kontroversielt. Då Fagfornyinga skulle utarbeidast, argumenterte den profilerte kulturjournalisten Inger Merete Hobbelstad for at «[a]lle sammen fortjener å få lese skjønnlitteratur utover den de finner frem av seg selv» (2017). Likeins argumenterer Weinreich for at ein fast skulekanon burde vore eit venstresideprosjekt i kraft av å fungere utjamnande, men også eit kulturradikalt prosjekt «fordi det tager udgangspunkt i kvalitet og bevidste valg frem for mekanisk konsum» (2004, s. 36). I praksis avviser også sjeldan kanonkritikarar verdien av å ha ein felles kanon; i staden tek dei til orde for å kritisk vurdere om utvalet er skeivt eller overser visse grupper (f.eks. Aamotsbakken, 2003, s. 22). At litteraturen som språkkunst blir rekna som ein særeigen diskurs, er tydeleg.

Eit interessant samanfall mellom dei to kriteria er at båe ofte blir underbygde av antakingar om at å lesa litteratur på eit eller anna vis skal gjera oss til betre menneske: meir empatiske og etisk reflekterte. Sjølv om den mest kjende kanonforkjemparen, Bloom, avviser at den tradisjonelle kanon er moralsk høgverdig, argumenterer både moderate kanonforsvararar som svenske PärYngve Andersson (2010, s. 97) og dei meir kanonkritiske, som norske Tonje Vold (2019, s. 37), for at litteratur kan vera etisk utviklande. På båe sider i debatten viser ein ofte til teoriar om narrativ empati og førestillingsevne formulerte av filosofen Martha Nussbaum. Desse omgrepa har vunne stor hevd i arbeidet for å legitimere skjønnlitteraturens plass i skulen (f.eks. Andersen, 2011; Andersson, 2010; Gabrielsen et al., 2019). Nussbaum meiner at litteraturundervisning må bidraga til verdsborgarskap ved at vi «både føyer nye tekster til den velkjente vestlige litterære 'kanon' og samtidig ser på standardtekstene med et veloverveid og kritisk blikk» (Nussbaum, 2016, s. 29). Såleis må det skjønnlitterære pensumet gjeva stemme til visse undertrykte samfunnsgrupper, «så som medlemmer av andre kulturer, etniske minoriteter, kvinner, lesbiske og homofile» (ibid., s. 43). Også i dette kanonkritiske resonnementet blir eit kvalitetskriterium implisert: 
Kvalitativt gode tekster er dei som dannar lesaren til å bli ein etisk medviten samfunnsborgar.

Det finst faktisk empirisk støtte for at litterær lesing gjer oss etisk medvitne og skaper empati med andre menneske. Dette gjeld når tekstene som blir brukte, er tematisk relevante, til dømes når fiktive karakterar representerer ei minoritetsgruppe (Schrijvers, Janssen, Fialho \& Rijlaarsdam, 2019, s. 34). Men også her ligg det ein uproblematisert premiss, nemleg at ein lærar på førehand kan vita kva som er tematisk relevant. Det er ikkje nødvendigvis barne- og ungdomslitteratur om samtidige tema som framstår som mest relevant for elevar (jf. Ommundsen, 2011; Penne, 2006, s. 370). Som Laila Aase skriv: «Norskfaget må ha mer å tilby elevene enn det som allerede ligger innenfor deres interessefelt, og den lærer som tror han vet hva elever interesserer seg for, kan komme til å ta skammelig feil» (2005, s. 78). Sjølv om idéane til Nussbaum utgjer ei kjærkomen legitimering for å undervise i skjønnlitteratur, er det usikkert i kva grad dei er overførbare til konkret undervisningspraksis. Nussbaum gjev òg lite støtte for refleksjonar om korleis ulike typar tekster rører ved lesarar på ulikt vis. Nettopp det uføreseielege i møtet mellom lesar og tekst er ei potensiell utfordring for den litterære utvalspraksisen. Like fullt kan ei hermeneutisk og dialogisk forståing av litterær kompetanse etter mi meining framheve det uføreseielege som ressurs. Med forankring i læreplanen for norskfaget vil eg vise at denne forståinga av litterær kompetanse kan reknast som overordna målsetjing for litteraturundervisninga.

\section{Litterær kompetanse, affekt og postkritikk}

Den svenske litteraturdidaktikaren Örjan Torell konstruerer ein treledda modell for litterær kompetanse. Han skil mellom det eg på norsk vil omtala som konstitusjonell kompetanse, performanskompetanse og overføringskompetanse [literary transferkompetens] (Torell, 2002, s. 82-88, figur 1). Den konstitusjonelle kompetansen er den medfødde evna til å skapa fiktive forteljingar, som er unik for mennesket. Delkompetansen performans inneber å kunna lesa på ein litteraturfagleg måte ved hjelp av innlærte konvensjonar for litterær lesing. Samstundes hevdar Torell at dersom opplæringa einsidig drillar elevar i å setja litteraturvitskaplege omgrep på element i ei tekst, blir litterær lesing ei mekanisk ferdigheit der forholdet mellom tekst og lesar og mellom tekst og omverd kjem i skuggen (Torell, 2002, s. 84). Det kan hevdast at vi ser tendensar til dette i den ovannemnde vektlegginga av «verkemiddel» i norskundervisninga. For at lesaren ikkje skal miste evna til å skapa eksistensiell meining ut frå tekstene, må performanskompetanse balanserast mot overføringskompetanse. For meininga i ei tekst kan berre realiserast i ein situasjon der lesaren identifiserer samanhengar mellom teksta og eiga erfaringsverd, men samtidig må ein elev kunna setja ord på lesinga på ein fagleg presis måte og dimed anerkjenne avstanden mellom fiksjonen og eige liv (Torell, 2002, s. 86-90). Dette kan visualiserast som ein kommunikasjon mellom teksta som $d u$ og lesaren som eg: 


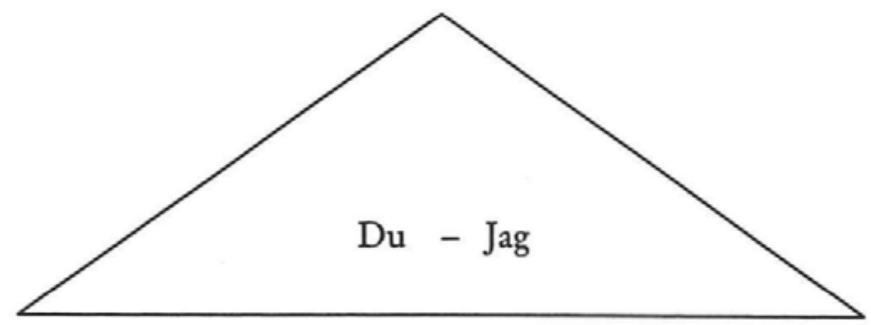

Performanskompetens

Literary transferkompetens

Figur 1. Litterær kompetanse (henta frå Torell, 2002, s. 82)

Både overførings- og performanskompetanse kan finne eit grunnlag i den nye læreplanen for norskfaget. Etter fjerde trinn er eit kompetansemål at eleven skal kunna lesa ulike litterære og sakprosasjangrar og «samtale om hva tekstene betyr for eleven» (Utdanningsdirektoratet, 2019, s. 6). Eleven ikkje berre kan, men skal reflektere over samanhengen mellom teksta og eige liv. Performanskompetanse er integrert i måla etter sjuande trinn, der eleven skal kunna «samtale om formål, form og innhold» (ibid., s. 7), og etter tiande trinn er også sjangertrekk og verkemiddel med (ibid., s. 9). Vidare er desse måla nedfelte i retningslinene for undervegsvurdering etter både 7. og 10. trinn. Modellen til Torell kan slik sett fungere som vegkart for læreplanmåla, og i avslutninga av artikkelen drøftar eg korleis dette kan implementerast gjennom dei inngangane til litteraturval eg skisserer nedanfor.

I ljos av modellen blir dessutan problema med både kvalitets- og representativitetskriteriet synlege. Forsvararane av den tradisjonelle kanon opererer med eit falskt medvit om at kvalitetskriteriet er allmenngyldig og autonomt, det vil seia lausrive frå individuelle lesarar. Men samtidig er også kanonkritikarane blinde for at representativitetskriteriet dreg med seg uuttala premissar om kva som vil ha relevans for elevar ut frå ein tanke om statisk gruppetilhøyrsle. Der dei fyrste ser bort frå den pedagogisk viktige overføringskompetansen, risikerer dei andre å blokkere for performanskompetanse utan å nødvendigvis oppnå subjektiv relevans for elevane. Ein teori om kva litteraturvalet i skulen kan gjera, må ta med i rekninga det uføreseielege i møtet mellom tekst og lesar.

Nettopp det uføreseielege og foranderlege i litterær lesing er eit hovudtema for amerikanske Rita Felski (2015), som argumenterer for det ho kallar ein postkritisk lesemåte. I tråd med dette omtalar eg retninga ho er eksponent for, som «postkritikk» i det fylgjande. Denne retninga er «post» i den forstand at ho posisjonerer seg som kritisk etterfylgjar av den litteraturvitskaplege metoden som gjerne blir kalla «symptomatisk lesing», ein metode kjenneteikna av ein idé om at «the most interesting aspect of a text is what it represses, and that [...] interpretation should therefore seek 'a latent meaning behind a manifest one'» (Best \& Marcus, 2009, s. 3). Den same metoden ligg til grunn for kanonkritikken, som nettopp hevdar at kvalitetskriteria byggjer på dominante premissar som produserer forteiingar og 
utelatingar. Konsekvensen er etter Felskis syn at moderne litteraturvitskap lenge har vore einsretta mot å avdekkje skjulte, undertrykkande ideologiar i tekster og andre kulturuttrykk, ei haldning ho kallar «mistankens hermeneutikk» ${ }^{2}$. Å la seg bli riven med av ei litterær tekst er i dette paradigmet politisk naivt; den føretrekte haldninga er kjøleg, distansert og analytisk (Felski, 2015, s. 17). Derimot meiner postkritikarar at kjensler og subjektiv respons ikkje er irrelevant og politisk naiv støy, men tvert om verdfullt i litterær lesing.

Like fullt avviser ikkje postkritikarane kritisk teori, men etterlyser lesingar som produserer alternative fortolkingar, slik Felski meiner dagens feministiske litteraturforsking i aukande grad gjer (2008, s. 9). Ho rettar skyts mot representativitetstenkinga ved å påpeike at kravet om at lesarar og karakterar må vera identiske for at lesarane skal kunna identifisere seg med teksta, er å oversjå evna litteraturen har til å fungere metaforisk (Felski, 2008, s. 44). Når eg i den fylgjande drøftinga primært vel å stø meg til Felski, er det for det fyrste for å framheve den didaktiske relevansen av litteraturteorien. Dette kan sjåast som eit svar på den indirekte oppmodinga som ligg i Margrethe Sønnelands påstand om at litteraturfaget som skulefag og litteraturvitskapen som akademisk disiplin har mykje å tilføre kvarandre gjensidig (2019, s. 111). Enkelt sagt er jo litteraturteori det stadig pågåande arbeidet med å reflektere omkring dei grunnleggjande rammene og prinsippa som formar måten vi les og fortolkar litteratur på (Felski, 2008, s. 2). For det andre legg Felski vekt på at den postkritiske lesemåten bør la seg inspirere av hermeneutikken. Dimed høver resonnementet hennar saman med Torells forståing av litterær kompetanse, som til gjengjeld gjer det mogleg å «didaktisere» litteraturteorien. ${ }^{3}$

Den postkritiske revurderinga av kritisk teori har eit viktig grunnlag i ei vending mot affektar i dagens litteraturvitskap (Anker \& Felski, 2017, s. 10). Ein mykje sitert definisjon av affektar stammar frå kulturteoretikaren Eric Shouse, som skil mellom tre omgrep: Kjensler er opplevingar som kan mælast og kategoriserast i samanlikning med andre opplevingar; emosjonar er måten vi syner fram kjensler på; medan affektar er førspråklege inntrykk som uvilkårleg får kroppen til å respondere på måtar vi ikkje medvite styrer (Shouse, 2005). I den dominerande litteraturvitskaplege forståinga av affekt, utvikla av dei franske filosofane Gilles Deleuze og Félix Guattari, ligg ein idé om det virtuelle til grunn: Alle objekt i verda, også tekster, ber på evner til å inngå i relasjonar med andre objekt (DeLanda, 2006, s. 10). Så lenge ei moglegheit i ei tekst ikkje er aktualisert, det vil seia så lenge lesaren ikkje har produsert akkurat den lesinga, er ho virtuell: ein uutnytta kapasitet. For at det virtuelle skal aktualiserast, må lesar og tekst koma i kontakt. Dette siste poenget legg også Felski til grunn for den postkritiske lesemåten, sjølv om ho hentar omgrepsapparatet frå vitskapsfilosofen Bruno Latour: «[A]ctors only become actors via their relations with other phenomena, as

\footnotetext{
${ }^{2}$ Omgrepet er henta frå Paul Ricœur (1965).

${ }^{3}$ Det kan òg presiserast at refleksjonar om undervisning gjennomsyrer Felskis resonnement, og at ho difor sjølv framhevar den pedagogiske verdien av teoriutviklinga.
} 
mediators and translators linked in cause and effect» (Felski, 2015, s. 164). $\AA$ leggje vekt på affektar inneber dimed å ikkje etablere ei fast forståing av kva ei litterær tekst formidlar og korleis teksta kan tenkjast å påverke lesaren. I staden kan det innebera å rekne ei litterær tekst som ein ikkje-menneskeleg aktør med virtuelle eigenskapar som kan aktualiserast i form av individuelle affektar.

Det postkritiske blikket styrer såleis merksemda mot den ustyrlege individualiteten som alltid er nedfelt i litterær lesing. Den affektteoretiske tilnærminga har fellestrekk med resepsjonsteori ${ }^{4}$, men med ei større vektlegging av lesing som noko som grip inn i, utfordrar og formar livet til lesaren slik det utfaldar seg gjennom tid (jf. Macé, 2011, s. 107). Dette problematiserer tanken om at litterær lesing skal bidraga til å danne eller representere ein ferdig identitet. Snarare ligg vekta på at vi kan utnytte litteraturens inngrep i livet vårt til å stadig vera i prosess. Spørsmålet om korleis litterære tekster kan veljast ut, blir slik flytt vekk frå eit ontologisk og normativt felt der ein interesserer seg for kva litteratur er og korleis litterær lesing bør gå føre seg. I staden blir undersøkingsfeltet performativt og deskriptivt: Kva kan litterære tekster gjera med oss, og vi med dei?

Felskis postkritikk gjev rik grorbotn for didaktisk refleksjon, og til dømes har Andersson (2019) argumentert overtydande for at denne retninga kan vera retningsgjevande i lyrikkundervisning. Denne artikkelen fylgjer slik sett opp tendensen til å gjera postkritikken relevant for undervisning, ved å knyte han spesifikt til litteraturval som praksis. I neste del skisserer eg tre moglege inngangar til ei nytenking om litteraturval, som eg kallar etisk, reparerande og aktualiserande. Omgrepstriaden utgjer eit forsøk på å presisere kva den postkritiske lesemåten kan bidraga med i litteraturdidaktikken, men skal ikkje forståast som uttømmande. Eg viser her til eit utval av dei teoretikarane Felski (2015) bruker for å utvikle sin postkritiske lesemåte, og forankrar inngangane i både den treledda modellen over litterær kompetanse og intensjonar formulerte i Fagfornyinga. Idéen om at litteratur har etiske verknader, er nedfelt i til dømes det tverrfaglege temaet «Demokrati og medborgerskap» (Utdanningsdirektoratet, 2019, s. 3). Ordet reparerande viser til ein særskilt måte å myndiggjera elevane som lesarar på ved å bruke overføringskompetanse. Endeleg tilbyr aktualiserande lesingar eit perspektiv på korleis framandarta tekster kan brukast, som svarar på Torells oppmoding om å ta vare på avstanden mellom tekst og lesar.

\section{Tre inngangar til litteraturval}

\section{Den etiske}

Den zambisk-amerikanske litteraturforskaren C. Namwali Serpell skil mellom to etablerte syn på feltet litterær etikk (2014, s. 71-72). På den eine sida finst idéen

\footnotetext{
${ }^{4} \mathrm{Jf}$. Wolfgang Isers forståing av lesehandlinga: «[D]er Text ist ein Wirkungspotential, das im Lesevorgang aktualisiert wird» (Iser, 1984, s. 7) [Teksta er eit verknadspotensial som blir aktualisert i leseprosessen, mi omsetjing].
} 
om at teksta skal vekkje empati gjennom at lesaren blir innvigd i perspektivet til ein annan, slik Nussbaum argumenterer for. På den andre sida står idéen om at den andre er fundamentalt annleis, nokon vi ikkje kan kjenne eller gripe fullt ut, ein idé som stammar frå filosofen Emmanuel Lévinas. Som eitt av fleire alternativ til å velja mellom to statiske forståingar av litterær etikk, føreslår Serpell å sjå pendling som ein usikkerheitsmodus lesinga kan produsere: «In such a mode, identification is unavoidable, then impossible, then necessary once more. It is the fling of the gesture towards the other and the swing back that approximates ethics» (ibid., s. 72). Slik skildrar ho litterær etikk som ein prosess der lesaren stadig skiftar mellom identifikasjon og distanse.

Litterære tekster bed oss om å gjera noko, og iblant får dei oss til å handle minimalt, ved å lesa høgt det som står, eller meir omfattande, ved å endre meiningar og oppfatningar om verda rundt oss (Serpell, 2014, s. 2). Samtidig er det teksta gjer med oss, forankra i det vi gjer med henne. Å produsere ei lesing av ei bok er dimed ikkje berre affektivt, men òg etisk på det viset at vi tek eit aktivt val om å møte teksta og gjera noko i det møtet. Den etiske verknaden av litterær lesing er såleis etter Serpells syn langt meir komplisert enn at vi lærer oss å ta dei riktige vala, eller føle med dei menneska som fortener empati. Vi lèt vår subjektivitet flyte over i dei karakterane og hendingane vi konstruerer, og blir dimed medskuldige i etiske problem. Som Torell påpeiker, kan ei for sterk vektlegging av performanskompetanse gjera at vår eigen medverknad til skapinga av teksta blir avgløymd til fordel for eit presumptivt objektivt blikk: Der er teksta, og her på utsida er eg, ein dommar. Motsett ei einsidig vektlegging av distanse erklærer Serpell polemisk: «... any interpretation of American Psycho is ... an interpretation of the reader» $(2014$, s. 216). Litterær lesing handlar difor ikkje berre om å stille seg til doms over handlingane til ein annan. I den grad vi har produsert desse handlingane som lesarar, stiller vi oss samtidig til doms over oss sjølve idet vi dømmer karakterane.

Også Serpell opererer med eit kvalitetsomgrep der den etisk verdfulle litteraturen er den som stadig held lesaren i rørsle. Dette overlappar med Johansens forståing av at «[s]tor litteratur er karakteriseret ved fraværet på løsninger, forsimplinger og entydige svar», og prega av «undecidability» eller «uforudsigelighed» (Johansen, 2015, s. 7). Slik kan det postkritiske blikket spela saman med den aukande interessa for utfordrande litteratur i litteraturdidaktisk forsking. Dette kan gjeva impulsar til eit kvalitativt godt litteraturval, basert på ei anna kvalitetsforståing enn den Bloom opererer med. Blooms kvalitetsomgrep er for det fyrste temporalt i og med at det føreset at gode tekster er gamle nok til at fleire lesargenerasjonar har vore fascinerte av dei. For det andre er det kvasi-autonomt ved at Bloom insisterer på at kvalitet er ein ibuande eigenskap i tekster, samtidig som dei altså må skapa reaksjonar i historiske lesarar som nødvendigvis er sosiale vesen med kulturelt betinga forståingshorisontar.

Motsett dette vil postkritikken framheve at lesaren må freiste å skapa meining ut or teksta for at det i det heile skal koma til synes eigenskapar som kan 
kvalitetsvurderast. Lesarar må bli konfronterte med noko ukjent, med erfaringar vi ikkje umiddelbart kan leva oss inn i, men der vi kanskje må pendle mellom empati og framandgjering. Som Shouse skriv:

Given the ubiquity of affect, it is important to take note that the power of many forms of media lies not so much in their ideological effects, but in their ability to create affective resonances independent of content or meaning. (Shouse, 2005, mi kursivering)

Eit postkritisk syn på litterær etikk har potensielt store konsekvensar for litteraturvalet: I staden for å velja tekster som skal representere anten identiteten til elevane eller den litterære kanon, må det litterære utvalet representere eit framandarta mangfald. Eit uforløyst spørsmål som dimed oppstår, er kva vi skal gjera med dei tekstene som potensielt formidlar undertrykkande tankegods. Eitt svar på dette spørsmålet kan vera det eg kallar den reparerande inngangen.

\section{Den reparerande}

Eve K. Sedgwick, ein av grunnleggjarane av queer teori, revurderte mot slutten av livet den symptomatiske lesepraksisen ho hadde bidrege til, ved å skilja mellom paranoide og reparerande lesingar. Blant postkritikarar har dette skiljet vorte ein sentral tankefigur (jf. Apter \& Freedgood, 2009; Best \& Marcus, 2009; Felski, 2008, 2015). Skiljet stammar frå psykoanalysen, der paranoia er ei haldning prega av frykt, angst og misunning. Men den paranoide kan reparere kjenslene ved å mentalt «setja saman» dei paranoiaskapande elementa til ein ny heilskap (Sedgwick, 2003, s. 128) - spissformulert: «just because you have enemies doesn’t mean you have to be paranoid» (ibid., s. 127). Både objektet for paranoia og det reparerte objektet er såleis kognitive produkt. Vi skaper dei gjennom å lesa og fortolke omverda, inkludert litterære tekster. Ved å reparere skaper det paranoide subjektet meining i ein kultur som tilsynelatande støyter det frå seg. Også den tradisjonelle skulekanon kan reparerast - ikkje ved å leggje inn nye tekster som skal representere ein etablert identitetskategori, men ved å spørja: Kan eg produsere ei forståing av denne teksta som er annleis enn den paranoide?

Reparerande lesingar er postkritiske også på det viset at dei vidareutviklar den revisjonistiske tendensen i poststrukturalistisk kanonkritikk. For eksempel oppmoda den feministiske kanonkritikaren Susan Hardy Aiken allereie på 1980-talet om å «effect a transformative re-reading that is also, in effect, a re-writing» (1986, s. 298). Eit aktuelt eksempel for grunnskulens litteraturdidaktikk kan vera diskusjonen omkring «n-ordet» som er brukt i ein del av den kanoniserte, skandinaviske barnelitteraturen (jf. Bjørkøy, 2011). Skal desse tekstene fjernast - eller kan vi produsere ei alternativ lesing? Dette krev at lesaren evnar å spørja «kva kan denne teksta tyde for meg?». I eit slikt tilfelle kan den affektive responsen på ubehagelege tekststader bli eit utgangspunkt for å myndiggjera lesaren til å produsere sjølvstendige tolkingar - og dimed eit verktøy for å byggje bru mellom overføring og performans. Med andre ord: Motstanden kontroversielle tekster byr på, er potensielt ei gullgruve for fortolkande refleksjon. 
Postkritikken problematiserer antakinga om at kunnskap i seg sjølv skal spore til etisk og politisk medviten handling. Å få informasjon om urettferd kan gjera tilhøyraren likegyldig eller til og med fiendsleg til den som lid (Sedgwick, 2003, s. 138). Ei reparerande lesing vil i likskap med symptomatiske lesemåtar identifisere grunnlaget for paranoia, men gjeva makt til eleven som lesar. Det dreiar seg ikkje om makt til å fjerne det vonde, men til å forvandle det og skapa reparerande gjenkjenning i eit samspel mellom teksta og «the fluctuating beliefs, hopes, and fears of readers» (Felski, 2008, s. 46). Den siste inngangen, som eg kallar «aktualiserande», er eit forsøk på å skildre nøyare korleis ei slik forvandling kan skje med eit affektteoretisk utgangspunkt.

\section{Den aktualiserande}

Ei vanleg forståing av omgrepet «aktualisering» i litteraturdidaktikken er at det handlar om å gjera framandarta litteratur relevant og forståeleg for dagens elevar (jf. Handesten \& Weinreich, 2001). I eit postkritisk og affektteoretisk perspektiv har det derimot ei anna tyding, noko som blir godt illustrert av den sveitsiske litteraturforskaren Yves Citton. Med utgangspunkt i ei deleuziansk forståing av virtualitet definerer han aktualisering som den prosessen der ein ubrukt kapasitet blir omsett i handling (2017, s. 525). Det handlar altså ikkje fyrst og fremst om å tematisere kva i teksta som er relevant for den tida og det samfunnet vi lever i, men om å gripe fatt i det ukjende, merkelege og intellektuelt utfordrande som virtualitet.

Gjennom å studere eldre litteratur går vi i dialog med andre moglege samfunn, noko som tvingar fram ei intellektuell desentrering liknande den vi har bruk for å praktisere i fleirkulturelle samfunn (Citton, 2017, s. 236). Også for Citton er altså den litterære lesinga kjenneteikna ved ei etisk utprøving, som kjem i stand ved at lesaren prøver ut dei «rollene» teksta tilbyr (ibid., s. 226-227). Forstått på denne måten er aktualisering å gjenoppfinne teksta:

Den 'riktige' forståinga søkjer ikkje å oppheve avstanden i tid mellom lesinga av i dag og skrifta av i (for)går(s), men å dra mest mogleg fordelar av at denne spenninga kan bringe fram noko nytt. ${ }^{5}$ (Citton, 2017, s. 63, mi omsetjing)

Her har Citton tydelege tilknytingspunkt til Johansens tankar om motstand. Johansen påpeiker at framandarta litteratur kan skapa meir rom for å merke seg dei estetiske kvalitetane i teksta, fordi det vil vera mindre rom for å projisere seg sjølv inn i henne (Johansen, 2015, s. 7). Dette kan vera ei retningsline for å byggje opp performanskompetanse; det framandarta ivaretek den nødvendige avstanden mellom tekst og lesar, og har, som Citton påpeiker, rikt didaktisk potensial. Den affektteoretiske idéen om aktualisering kan såleis knytast til det dialogiske synet på litterær kompetanse. Også den amerikanske litteraturdidaktikaren Sheridan Blau framhevar at å akseptere eigne feiltolkingar og å tolerere tvitydigheiter,

\footnotetext{
5 «La 'bonne' compréhension ne cherche pas à abolir la distance temporelle entre l'aujourd'hui de la lecture et l'(avant-)hier de l'écriture, mais à exploiter au mieux sa tension productrice de nouveauté.»
} 
paradoks og usikkerheiter i teksta er viktige dimensjonar i den performative litterære kompetansen (2003, s. 210-211). Arbeid med litterære tekster kan slik sett vera ein måte å øve opp evna til å ikkje koma fram til sikker kunnskap, noko som kan vera ein viktig eigenskap også på andre område enn i arbeid med litterære tekster.

Citton kan i likskap med tradisjonelle kanonforsvararar seiast å privilegere den eldre litteraturen og ei temporal kvalitetsforståing. Men på eitt viktig punkt skil han seg frå Bloom. Sistnemnde er ein forsvarar av den klassiske danninga, og målber eit elitistisk syn om at det finst ein særleg litterær kompetanse som berre skulerte lesarar har. Derimot ser Citton det å ikkje forstå, det å «mangle» kunnskap, som ein styrke. Til dømes kan det å ha eit anna morsmål enn majoriteten, eller å mangle nokre av majoritetskulturens referansar, vera ein fordel dersom føremålet er å dyrke evna til å møte teksta på ein open måte, utan å forstå alt (Citton, 2017, s. 236). Til grunn for denne tanken om aktualisering ligg eit demokratisk prinsipp: Alle har tilgang til også framande, utfordrande og ukjende tekster. Dette gjeld sjølvsagt òg majoritetsspråklege, på det viset at born kan bringe fram andre og uventa forståingar av ei tekst enn vaksne. Til dømes vil born ofte ikkje tolke inn den tredje dimensjonen i illustrasjonane i biletbøker, det vil seia at dei ikkje vil oppfatte at bileta har djupne (Rhedin, 2004, s. 19-20). Nett dette er jo er ein tillært konvensjon og ikkje den einaste riktige måten å fortolke på. At born ikkje har tileigna seg slike konvensjonar, er ein didaktisk ressurs i kraft av å kunna problematisere fortolkinga til den vaksne.

Ikkje minst kan aktualisering tilby ein nyttig tankekategori i møte med det norskfaglege kjerneelementet «tekst i kontekst», der det heiter at «tekstene skal knyttes både til kulturhistorisk kontekst og til elevenes egen samtid» (Utdanningsdirektoratet, 2019, s. 2). For også det kontekstuelle og det samtidige er kognitive produkt som vi potensielt kan skapa ut av alle slags tekster. Den franske litteraturforskaren Marielle Macé skriv: «Alle verk har faktisk 'ein dåm av noko gamalt' [...]. Det eg les, er altså ikkje det som uttrykkjer meg, men det som liknar meg, som kallar meg til meg sjølv og krev at eg tek eit krafttak mot meg sjølv.» ${ }^{6}$ (2011, s. 214, mi omsetjing). Ligg det ikkje i litteraturens vesen å bryte vår forståingshorisont mot noko framandt - uansett om dette framande høyrer til samtida eller den fjerne fortida? Vidare argumenterer Macé for at romanar ikkje nødvendigvis gjer oss betre eller meir lukkelege, men ganske enkelt betre skikka til å plassere oss sjølve, og bevege oss gjennom andre tidsformer, liknande og forskjellige frå vår eiga (2011, s. 124-125). Å lesa ei litterær tekst er på den eine sida å gå ut av seg sjølv og oppleva noko nytt, men også å koma attende til seg sjølv, og skapa seg sjølv på ny.

\footnotetext{
${ }^{6}$ «Toute œuvre a en effet 'un air d'ancienneté' [...]. Ce que je lis, alors, n'est pas ce qui m'exprime, mais ce qui me ressemble, ce qui m'appelle vers moi et requiert de moi un effort contre moi.»
} 


\section{Avslutning: Verdien av affektiv hermeneutikk}

Det ideologikritiske synet på kanon manglar eit blikk for at identitet er ein prosess, ei utvikling, noko som stadig kan utfordrast og omformast i møte med andre erfaringar og forståingar (Felski, 2008, s. 11). Motsett dette er den blinde flekken hjå kanonforsvararar som Bloom at det transhistoriske og autonome kvalitetskriteriet i røynda er og må vera historisk og kulturelt fundert. I denne artikkelen har eg teke til orde for eit postkritisk syn på litterær lesing, som eg meiner får fram verdien i litteraturens potensielle verknader i møte med ulike lesarar, framfor å ta utgangspunkt i at litteraturen skal ha spesielle effektar. Der mange litteraturdidaktikarar entusiastisk argumenterer for at litterære tekster har ein empativekkjande verknad, vil den postkritiske skildringa av møtet mellom lesar og tekst snarare hevde at forholdet mellom lesing og etikk er meir komplekst og mørkt enn det ein greier å fange opp med ein ukritisk bruk av idéane til Nussbaum.

I eit postkritisk perspektiv er litterær lesing ein prosess med ukjent utfall der lesaren aktualiserer den affektive virtualiteten i ei tekst. Dette opnar for å tenkje annleis om kva tekster eigentleg «representerer», samtidig som verdien i tekster som byr på kompleksitet, motstand og det uføreseielege (jf. Johansen, 2015) kan forankrast teoretisk. Dei tre inngangane til litteraturval ovanfor står i motsats til eit underkastande og ukritisk kanonsyn, der idéen er at «[d]e stora verken tolkar sig själva» (Persson, 2007, s. 84). Lesaren må aktivt og vyrdlaust skapa meining av teksta, men å kritisere ideologien i henne er berre éin måte å gjera dette på.

Avslutningsvis er det eit viktig spørsmål korleis det postkritiske synet på litteratur og lesing kan integrerast i skulen, der kompetanse skal vurderast i tråd med læreplanmål. Det kan verke som at målstyring eignar seg best til å vurdere performanskompetanse, medan det individuelle og affektive møtet mellom tekst og lesar har mest å gjera med litterær overføringskompetanse, og vanskeleg kan vurderast. Litteraturforskar Lars August Fodstad spør retorisk: «Er det for eksempel mulig å målstyre utforskingen av en litterær tekst uten å undergrave selve poenget med å utforske den?» (2019, s. 73). Dette heng saman med det Kari Anne Rødnes framhevar som ei sentral litteraturdidaktisk utfordring, nemleg å undervise på ein måte som skaper dialog «mellom erfaringsbaserte og analytiske perspektiver på teksten» (2014, s. 15). Her ligg det ein verdi i det postkritiske argumentet om at affekt og fortolking «are intertwined rather than opposed», slik at vi kan prata om ein affektiv hermeneutikk (Felski, 2015, s. 177-178). I kombinasjon med Torells triangulære modell framhevar postkritikken at litterær kompetanse føreset balanse mellom affekt og fortolking, mellom erfaring og analyse, mellom overføring og performans - og at det å prioritere det eine på kostnad av det andre er ein blindveg.

Ein metodologisk innfallsvinkel til korleis affektiv hermeneutikk kan sjå ut i morsmålsundervisninga, finn vi i den ovannemnde framveksande interessa for utfordrande tekster. Sønneland føreslår ei problembasert litteraturundervisning, der læraren lèt elevane koma «i berøring med problemet» (2018, s. 95). Ho viser 
at det er grunn til å ha tillit til at elevar kan engasjere seg i tekster, og at det difor kan løne seg å arbeide med «åpenhet først og prosedyre etterpå» (ibid.). Dette kan til dømes gå ut på å la elevane utforske ei litterær tekst, og deretter la det vera lærarens rolle å kople utforskinga til eit fagspråk. Ei slik litteraturundervisning ville ikkje vore målstyrt på det viset at undervisningsopplegget er designa for at det singulære tekstarbeidet skal få elevane til å «samtale om hva tekstene betyr for eleven» eller «reflektere over hvordan tekster framstiller møter mellom ulike kulturer» (Utdanningsdirektoratet, 2019, s. 6, 10). Men det er grunn til å tru at ei slik problembasert undervisning tek vare på balansen mellom performans- og overføringskompetanse, og dimed indirekte kjem læreplanmåla i møte. På akkurat dette punktet er det eit openbert behov for vidare forsking.

I staden for å sjå konflikten mellom målstyring og open utforsking som eit problem, ville ei problembasert litteraturundervisning utnytte moglegheita litterære tekster har til å aktualisere noko i både teksta og lesaren for å setja i gong ein prosess. Læraren måtte prata mindre om verkemiddel og heller ta utgangspunkt i det elevane veit - og ikkje veit. Vegen er målet. Forvirring er bra. Det ukjende kan gjerne bli verande ukjent.

\section{Om forfattaren}

Per Esben Myren-Svelstad er førsteamanuensis i norskdidaktikk ved NTNU i Trondheim. Han forskar på kanonproblematikk i litteraturundervisninga, økokritikk, grafisk litteratur, og kjønn, seksualitet og identitet i litteratur.

Institusjonstilknyting: Institutt for lærarutdanning, NTNU, 7491 Trondheim.

E-post: per.svelstad@ntnu.no

\section{Referansar}

Aiken, S. H. (1986). Women and the Question of Canonicity. College English, 48, 288-301. Andersen, P. T. (2011). Hva skal vi med skjønnlitteraturen i skolen? Norsklceraren, 35(2), $15-22$.

Andersson, P.-Y. (2010). Tid för litteraturdidaktiskt paradigmskifte? Tidskrift för litteraturvetenskap, 40(3-4), 91-106.

Andersson, P.-Y. (2019). Lyrikläsning som didaktisk praktik. Norsk pedagogisk tidsskrift, 103(1), 65-76.

Anker, E. S. \& Felski, R. (2017). Introduction. I E. S. Anker \& R. Felski (red.), Critique and Postcritique (s. 1-28). Durham \& London: Duke University Press.

Apter, E. \& Freedgood, E. (2009). Afterword. Representations, 108(1), 139-146. https://doi.org/10.1525/rep.2009.108.1.139

Best, S. \& Marcus, S. (2009). Surface Reading: An Introduction. Representations, 108(1), 1-21. https://doi.org/10.1525/rep.2009.108.1.1

Bjørkøy, A. M. B. (2011). Da Hoa og negermann forsvant. Om revisjon av Egner og neger. Nytt norsk tidsskrift, 28(4), 359-369. 
Blau, S. (2003). The Literature Workshop. Teaching Texts and their Readers. Portsmouth: Heinemann.

Bloom, H. (1994). The Western Canon: The Books and Schools of the Ages. New York: Harcourt Brace.

Citton, Y. (2017). Lire, interpréter, actualiser. Pourquoi les études littéraires? Paris: Éditions Amsterdam.

DeLanda, M. (2006). A New Philosophy of Society. Assemblage Theory and Social Complexity. London: Continuum.

Felski, R. (2008). Uses of Literature. Oxford: Blackwell.

Felski, R. (2015). The Limits of Critique. Chicago \& London: University of Chicago Press.

Fodstad, L. A. (2019). Fortsatt kulturfag? Norsk på nytt. I M. Blikstad-Balas \& K. R. Solbu (red.), Det (nye) nye norskfaget (s. 61-81). Bergen: Fagbokforlaget.

Gabrielsen, I. L., Blikstad-Balas, M. \& Tengberg, M. (2019). The Role of Literature in the Classroom: How and for What Purposes Do Teachers in Lower Secondary School Use Literary Texts? L1-Educational Studies in Language and Literature, 19, 1-32.

Hamre, P. (2014). Norskfaget og skjønnlitteraturen. Ein studie av norskfaglege normtekstar 1739-2013. Doktoravhandling, Universitetet i Bergen.

Handesten, L. \& Weinreich, T. (2001). Litteraturens byrde: Litteraturhistorie og celdre tekster i folkeskolen i teori og praksis. Fredriksberg: Roskilde Universitetsforlag.

Hobbelstad, I. M. (2017, 9.11). Norskfaget: Hvem måler det elevene går glipp av? Dagbladet. https://www.dagbladet.no/kultur/norskfaget-hvem-maler-det-elevene-gar-glippav/68864193

Haarberg, J. (2017). Nei, vi elsker ikke lenger. Litteraturen og nasjonen. Oslo: Universitetsforlaget.

Iser, W. (1984). Der Akt des Lesens. Theorie ästhetischer Wirkung. München: Wilhelm Fink. Johansen, M. B. (2015). ”Jeg har forstået den sådan, at den ikke skal forstås” - når 6.A. læser Franz Kafka. Acta Didactica Norge, 9(1), Art. 6. https://doi.org/10.5617/adno.1391

Kjelen, H. (2013). Litteraturundervisning i ungdomsskulen. Kanon, danning og kompetanse. Doktoravhandling, NTNU.

Lie, T. (2018, 18.9). Steile fronter i debatten om avkolonisering av akademia. Khrono. https://khrono.no/saih-professorer-beathe-ogard/steile-fronter-i-debatten-omavkolonisering-av-akademia/237372

Macé, M. (2011). Façons de lire, manières d'être. Paris: Éditions Gallimard.

Nussbaum, M. C. (2016). Den narrative forestillingsevne (A. Øye, oms.). I I. Engelstad (red.), Litteraturens etikk: Følelser og forestillingsevne (s. 25-57). Oslo: Pax.

Ommundsen, Å. M. (2011). Synnøve Solbakken i det flerkulturelle klasserommet. Norsklcereren, 35(3), 57-65.

Penne, S. (2006). Profesjonsfaget norsk i en endringstid. Norsk på ungdomstrinnet. $\AA$ konstruere mening, selvforståelse og identitet gjennom språk og tekster. Fagets rolle i et identitetsperspektiv, i et likhet- og i et ulikhetsperspektiv. Doktoravhandling, Universitetet i Oslo.

Persson, M. (2007). Varför läsa litteratur? Om litteraturundervisningen efter den kulturella vändningen. Lund: Studentlitteratur.

Rhedin, U. (2004). Bilderbokens hemligheter. Stockholm: AlfabetaAnamma.

Ricœur, P. (1965). De l'interpretation: essai sur Freud. Paris: Seuil.

Rødnes, K. A. (2014). Skjønnlitteratur i klasserommet: Skandinavisk forskning og didaktiske implikasjoner. Acta Didactica Norge, 8(1), Art. 5. https://doi.org/10.5617/adno.1097

Schrijvers, M., Janssen, T., Fialho, O. \& Rijlaarsdam, G. (2019). Gaining Insight Into Human Nature: A Review of Literature Classroom Intervention Studies. Review of Educational Research, 89(1), 3-45. https://doi.org/10.3102/0034654318812914 
Sedgwick, E. K. (2003). Touching Feeling. Affect, Pedagogy, Performativity. Durham \& London: Duke University Press.

Serpell, C. N. (2014). Seven Modes of Uncertainty. Cambridge: Harvard University Press.

Shouse, E. (2005). Feeling, Emotion, Affect. M/C Journal, 8(6). http://journal.mediaculture.org.au/0512/03-shouse.php/

Skaug, S. \& Blikstad-Balas, M. (2019). Hele tekster versus utdrag - hvilke tekster velger norsklærerne? Nordic Journal of Literacy Research, 5(1), 85-117.

Smithson, I. (1994). Introduction: Institutionalizing Culture Studies. I I. Smithson \& N. Ruff (red.), English Studies/Culture Studies: Institutionalizing Dissent (s. 1-22). Urbana \& Chicago: University of Illinois Press.

Steinfeld, T. (2009). Norsk kanon og kanondannelse: Historiske linjer, aktuelle konflikter og utfordringer. TijdSchrift voor Skandinavistiek, 30(1), 167-191.

Sønneland, M. (2018). Innenfor eller utenfor? En studie av engasjement hos tre 9. klasser i møte med litterære tekster som faglige problem. Nordic Journal of Literacy Research, 4(1), 80-97.

Sønneland, M. (2019). Teksten som problem. En studie av littercere samtaler i ungdomsskolen. Doktoravhandling, Universitetet i Stavanger.

Torell, Ö. (2002). Resultat - en översikt. I Ö. Torell (red.), Hur gör man en litteraturläsare? (s. 74-100). Härnösand: Institutionen for humaniora.

Utdanningsdirektoratet (2019). Læreplan i norsk. https://data.udir.no/kl06/v201906/laereplaner-lk20/NOR01-06.pdf

Vinje, E. (2005). Om kanon i litteraturundervisninga. I B .K. Nicolaysen \& L. Aase (red.), Kulturmøte i tekstar: Litteraturdidaktiske perspektiv (s. 72-87). Oslo: Samlaget.

Vold, T. (2019). A lese verden. Fra imperieblikk og postkolonialisme til verdenslitteratur og økokritikk. Oslo: Universitetsforlaget.

Weinreich, T. (2004). Kanon - litteratur i folkeskolen. København: Høst \& Søn.

Aamotsbakken, B. (2003). Skolens kanon - vår viktigste lesedannelse? En studie i kanonisering i norskfaglige antologier for videregående skole, allmennfaglig studieretning. Tønsberg: Høgskolen i Vestfold.

Aamotsbakken, B. (2008). Kvinnelige forfattere i lærebøker - kanonisert eller kandisert? I D. Skjelbred \& B. Aamotsbakken (red.), Norsk lærebokhistorie - en kultur- og danningshistorie (s. 145-164). Oslo: Novus forlag.

Aamotsbakken, B. (2015). En marginalisert litteratur? Representasjon av samiske tekster i norskfaglige læremidler for ungdomstrinnet. Norsk pedagogisk tidsskrift, 99(3-4), 282293.

Aase, L. (2005). Norskfaget - skolens fremste danningsfag? I K. Børhaug, A.-B. Fenner \& L. Aase (red.), Fagenes begrunnelser. Skolens fag og arbeidsmåter i danningsperspektiv (s. 69-83). Bergen: Fagbokforlaget Vigmostad \& Bjørke. 